\title{
Risk factors in dropping out of nursing studies
}

\author{
Milagros De la Rosa Hormiga ${ }^{1}$, Candelaria de la Merced Díaz-González², Josefa María Ramal López ${ }^{3}$, \\ Juan Manuel Herrera Hernández ${ }^{1}$ \\ ${ }^{1}$ Universidad de La Laguna, San Cristóbal de La Laguna, Spain \\ ${ }^{2}$ Universidad de Las Palmas de Gran Canaria, Nurse of Hospital Insular de Gran Canaria, Las Palmas de Gran Canaria, Spain \\ ${ }^{3}$ Universidad de Las Palmas de Gran Canaria, Las Palmas de Gran Canaria, Spain \\ Email: cloehormiga@gmail.com, cmdiazglez@yahoo.es,jramal@denf.ulpgc.es, jherera@ull.es
}

Received 28 October 2013; revised 2 December 2013; accepted 16 December 2013

Copyright (c) 2014 Milagros De la Rosa Hormiga et al. This is an open access article distributed under the Creative Commons Attribution License, which permits unrestricted use, distribution, and reproduction in any medium, provided the original work is properly cited. In accordance of the Creative Commons Attribution License all Copyrights @ 2014 are reserved for SCIRP and the owner of the intellectual property Milagros De la Rosa Hormiga et al. All Copyright (C 2014 are guarded by law and by SCIRP as a guardian.

\section{ABSTRACT}

School failure is a worrying phenomenon of the educational system that affects most sectors of the education regarding parents, teachers and students and covers education at all levels, from basic education levels to higher levels. One of the levels where there is a high incidence of this problem is in university education, where dropout rates at university are between $\mathbf{2 5 \%}$ and $50 \%$ in the early formative years. Therefore, it is considered that this phenomenon of school failure and dropout must be addressed and treated from all support systems and services that merge at school, because there are many interests involved not only in the student who fails himself, but also in society in general. The objective of this survey is finding out the effects of anxiety and personal problems in ULPGC nursing students and the consequences that can bring in their academic performance. The results obtained show direct influence of variables such as attendance, studies organization, disappointment feelings, approaching dropout and others, however the hypotheses that were not met differentially, offer us relevant information, for better understanding and making decisions to prevent school failure at university.

\section{KEYWORDS}

\section{School Failure; Higher Education; Anxiety}

\section{INTRODUCTION}

The use of the concept "school failure" has been recurrent when considering reforms and changes in modern educational systems [1]. However, we should have in mind that we are facing a polysemic and ambiguous con- cept which can be interpreted and used according to specific political and ideological interests.

In general, the term "school failure" is usually applied to students and makes reference to those who fall back behind the educational system in some sections, or who have failed a basic training that allows them to integrate into society by themselves [2]. However, the most common indicator to quantify failure is the percentage of students who are dropping out the system prematurely and those who fail to achieve titling without allowing them to continue their post-compulsory studies [3].

School failure occurs when something goes wrong at some points in the educational system, i.e., it fails some educational action that is not oriented correctly $[2,4,5]$.

It could be defined as a mismatch between the proposed learning process and student learning process that prevents him from progressing through the educational pyramid system [1]. The debate arises in place if it is the student himself or the system that generates academic failure [1].

Learning difficulties that can lead to school failure depend on social, family, individual, pedagogical and medical factors [6]. Determining their origin is essential to know where to focus on their solutions. In fact, according to some trends that come from studying academic failure, it indicates more focuses on social classes with fewer resources, since both family and faculty expectations are impoverishing, and from a beginning, it does not question the social reprocuction role that school plays [7]. The compensatory response that it should offer is mistaken with a downward adaptation, instead of opening expectations and enriching the learning, causing a progressive disinterest and neglect [6].

The mistake could be anywhere on the educational system (educational centers, legislation, inspection) as well 
as other factors like excessive contents, curriculum fragmentation, teacher education, resources provided, the investment in education or lack of democracy in schools, etc. [8] (when these are precisely those that can affect the most on the educational system to avoid failure).

If we consider that primary education and most of the secondary education are mandatory, we must also keep in mind that university is not [9]. When failure occurs within the scope of school as something that is imposed and mandatory from the education system, while in the university field the access is done by your own will and choice where it is assumed that students count on minimum competencies to be completed by the system imposed and current academic models [9].

Moreover, we can not focus on a single factor that affects university academic failure, but in a number of factors that focus on each student when the educational goals that are set at a certain level or educational system are not achieved $[7,8,10]$.

Also, we can define or understand failure as a negative reality, but also as a negative concept for not meeting expectations, goals or objectives set by university students.

On the other hand, we can address failure in a series of quantitative and qualitative terms. In the former, ruled by three variables, we will focus on university dropout rates, the rate of students repeating university academic courses and comparison of students who complement their studies within the stipulated time for each titling; and the latter addresses the failure as a function of factors involving the student [3].

As we have noted, university education is one of the areas where most of the work was done on the study of failure and the causes that bring abandonment due to the high rates that are being made and their impact on different areas [9]. In fact, university students dropout is a problem that affects directly not only students themselves, due to the effect that occurs at different levels, but also the personal, educational or psychological ones, and also the university institution and society itself, since these students leave their educational course without having achieved their objectives and university degree that will enable them for professional practice [8]. Also, such dropout is also closely related to failure, being one of the previous factors that affect itself [8].

Finally, it emphasizes that school failure does not have an entire objective side, because it is subject to students expectations, teachers and even university institution itself [3].

Since a few years Spanish higher education is going through a major restructuring process, it can be seen by the growing number of private universities, studies adaptation to business needs, the need to converge with other members of the European Union, etc. [1].
These changes require thinking about the need for institutional reforms to adapt their objectives to these new social needs, but without losing sight of the ultimate purpose of the system, its effectiveness, translated into success rates of their addressees [3]. This guiding principle for any institution is becoming more and more questioned at university, being at present time one of the organizations with a greater "dropout index", translated into "failure index", after compared to the number of students who enroll with the ones that finish their studies successfully [9].

Academic performance in higher education is a concerning matter due to the high social cost of each graduated student; for the added cost created when a student is studying for a longer period of time, or the cost does not become profitable when it does not finish; for quality reasons and social accountability; because it put us in places far below from other European countries, with whom we have to converge at the moment, being at the same level, etc. [8].

We can mention some theories and models who value academic dropout as the Model of Adaptation, which is the one that had the biggest boom when referencing a large number of studies and researches, according to this model [11]; dropout occurs due to the insufficient adaptation and integration of the student at school and social enviroment of university education. Within this model we can highlight Vincent Tinto's persistence theory; this theory explains the process of persistence in higher education, as a function of the adjustment level between the student and the institution, acquired from academic and social experiences (integration). Tinto [11] evaluated social integration degree through the development level and frequency of positive interactions with peers and teachers and throughout the degree of participation in extracurricular activities. Therefore, he discovered that integration throughout these two dimensions was causing a very strong commitment between the student and his institution, thereby increased the persistence.

He stated that students who feel that don't fit into the enviroment and have no sense of belonging to a community tend to be isolated, and therefore drop out when they find out other alternatives to invest their time, energies and resources, with more profits and lower costs.

Tinto's theory shows the need for universities to assume a proactive role in the process of student integration. Some authors report that this theory is specifically granted to students in traditional academic situations, i.e., classes that require attendance at a center, but it is not valid for non-attendance education instead.

Also within this model, we find Holland's theory (1966) [12], which tell us that adaptation possibilities and personal success are based on the characteristics of each student's personality, so depending on these traits 
there will be more or less suitable enviroments for adaptation.

\section{HYPOTHESIS}

Six hypotheses have been raised in this study; each hypothesis that it wants to be demonstrated (Ha), brings associated another null hypothesis (Ho), that will be the one used to find whether there is dependence between variables and accepting or rejecting our initial hypotheses.

1) In the way student perceives the teacher's influence can affect on their decision to attend class (Ha).

2) Lack of economic aids for education can influence on the approach for dropping out university studies (Ha).

3) Lack of organization generates anxiety in the studies (Ha).

4) Feeling of failure at university studies may be influenced by unfulfilled initial expectations about the degree chosen (Ha).

5) Perception by students of a teacher's positive influence can decrease the chances of failure at university studies (Ha).

6) The island where student comes from can influence dropping out at university (Ha).

\section{METHOD}

Designs: It was made a transversal observational analytical study. The scope it was coducted at the University of Las Palmas de Gran Canaria, School of Nursing, 2010-2011 academic year.

Individuals: The population under study was the $2^{\text {nd }}$. course of Nursing Degree, consisting of 47 students. This is the first group of students while doing a degree in nursing and voluntarily deciding to change the grade, adapting well to the new demands for European Space Superior Education (ESSE).

Definition of variables: As independent used variables: Age, sex, island of origin, government financial aids (scholarships), as sociodemographic variables, adding up two more types, type of teacher's influence, degrees of influence perceived by the students, etc.

As dependent used variables: Attendance to class and its frequency, studies organization, presence of anxiety, feeling of current failure and/or have suffered at some point, disappointment feeling, intentions of ending studies, approaching dropout.

Definition of variables:

1) Influence of the teacher: perceived by the student if it is positive, negative or indifferent.

2) Teacher's influence degree: perceived by the student and quantified by the influence of the teacher on his educational process.

3) Economic aids: if he gets or not any kind of gov- ernment aids, scholarships.

4) Attendance to class: this way, what it is intended is the consideration of attending class quite often.

5) Studies organization: if it's got study habits and if the study guidelines are suitable.

6) Anxiety: if it has suffered anxiety episodes during its career or not.

7) Failure: lack of success perception in current studies or have suffered at some point during the course.

8) Approaching dropout: ending titling or not.

9) Disappointment: dissatisfaction feeling by the student for not achieving the chosen career and initial expectations, whether it is present or not.

Data analysis: We opted for expressing the quantitative variable as a measure of centralization the arithmetic average and as scattering the standard deviation, while qualitative variables were expressed as absolute frequency and percentage, respectively.

For accepting or rejecting hypotheses initially raised in this survey, it was used chi-squared, since each variable (qualitative) has two or more categories, and this test provides a level of significance that will allow us later to determine the degree of dependence between the two variables that are being studied. To verify each of the six hypotheses, a Null hypothesis (Ho) was assigned to each one of them, which would serve us to accept or reject the Alternative hypothesis (Ha), which is the equivalent to those raised in this survey, in all of them expressed their contrast for a $5 \%$ significance.

SPSS 17.0. statistical package was used as IT support.

\section{ETHICAL CONSIDERATIONS}

Prior distribution of questionnaires, students being present at class were verbally informed, as request for their participation on a voluntary anonymous way.

\section{RESULTS}

A 47 questionnaires were given, all collected and validated, thus, a sample of 47 students. The average age for students, it was 22.3 years and the standard deviation (DE) of 4.408 . The 34\% (16) were men and 66\% (31) women. The home islands were Gran Canaria with 91.5\% (43) and Lanzarote with $8.5 \%$ (5) students. The $21.3 \%$ (10) are grantees, against a majority of $78.7 \%$ which it is not (Table 1).

A $44.7 \%$ (21) refers attending to class on some occasions, a $40.4 \%$ (19) on a frequent basis and $14.9 \%$ (7) rarely attends.

The questionnaire shows that a $61.7 \%$ (29) studying only before the exams, a $19.1 \%$ studying every day and the same percentage on weekends. Regarding the second question about the study tools: $72.3 \%$ (34) it is done through class notes. 
Table 1. Sample frecuency.

\begin{tabular}{|c|c|c|c|c|c|}
\hline & & Frequency & Percent & Valid Percent & Cumulative Percent \\
\hline Sex & $\begin{array}{c}\text { Male } \\
\text { Female } \\
\text { Total }\end{array}$ & $\begin{array}{l}16 \\
31 \\
47\end{array}$ & $\begin{array}{c}34.0 \\
66.0 \\
100.0\end{array}$ & $\begin{array}{c}34.0 \\
66.0 \\
100.0\end{array}$ & $\begin{array}{c}34.0 \\
100.0\end{array}$ \\
\hline Island of origin: & $\begin{array}{c}\text { Gran Canaria } \\
\text { Lanzarote } \\
\text { Total }\end{array}$ & $\begin{array}{c}43 \\
4 \\
47\end{array}$ & $\begin{array}{c}91.5 \\
8.5 \\
100.0\end{array}$ & $\begin{array}{c}91.5 \\
8.5 \\
100.0\end{array}$ & $\begin{array}{c}91.5 \\
100.0\end{array}$ \\
\hline Scholarships & $\begin{array}{c}\text { A scholarships } \\
\text { No scholarchips } \\
\text { Total }\end{array}$ & $\begin{array}{l}10 \\
37 \\
47\end{array}$ & $\begin{array}{c}21.3 \\
78.7 \\
100.0\end{array}$ & $\begin{array}{c}21.3 \\
78.7 \\
100.0\end{array}$ & $\begin{array}{c}21.3 \\
100.0\end{array}$ \\
\hline When Studying & $\begin{array}{l}\text { Just to test } \\
\text { One weekend } \\
\text { Every day } \\
\text { Total }\end{array}$ & $\begin{array}{c}29 \\
9 \\
9 \\
47\end{array}$ & $\begin{array}{c}61.7 \\
19.1 \\
19.1 \\
100.0\end{array}$ & $\begin{array}{c}61.7 \\
19.1 \\
19.1 \\
100.0\end{array}$ & $\begin{array}{c}61.7 \\
80.9 \\
100.0\end{array}$ \\
\hline Attendance: & $\begin{array}{c}\text { Usually } \\
\text { Sometimes } \\
\text { Does not attend } \\
\text { Total }\end{array}$ & $\begin{array}{c}19 \\
21 \\
7 \\
47\end{array}$ & $\begin{array}{c}40.4 \\
44.7 \\
14.9 \\
100.0\end{array}$ & $\begin{array}{c}40.4 \\
44.7 \\
14.9 \\
100.0\end{array}$ & $\begin{array}{c}40.4 \\
85.1 \\
100.0\end{array}$ \\
\hline Teacher Influence: & $\begin{array}{l}\text { Positive } \\
\text { Negative } \\
\text { Indistinct } \\
\text { Total }\end{array}$ & $\begin{array}{c}41 \\
0 \\
6 \\
47\end{array}$ & $\begin{array}{c}87.2 \\
0 \\
12.8 \\
100.0\end{array}$ & $\begin{array}{c}87.2 \\
0 \\
12.8 \\
100.0\end{array}$ & $\begin{array}{c}87.2 \\
0 \\
100.0\end{array}$ \\
\hline Finish studies: & $\begin{array}{c}\text { Yes } \\
\text { No } \\
\text { Sometimes } \\
\text { Total }\end{array}$ & $\begin{array}{c}37 \\
1 \\
9 \\
47\end{array}$ & $\begin{array}{c}78.7 \\
2.1 \\
19.1 \\
100.0\end{array}$ & $\begin{array}{c}78.7 \\
2.1 \\
19.1 \\
100.0\end{array}$ & $\begin{array}{c}78.7 \\
80.9 \\
100.0\end{array}$ \\
\hline Approaching Dropout: & $\begin{array}{c}\text { Yes } \\
\text { No } \\
\text { Total }\end{array}$ & $\begin{array}{c}6 \\
41 \\
47\end{array}$ & $\begin{array}{c}12.8 \\
87.2 \\
100.0\end{array}$ & $\begin{array}{c}12.8 \\
87.2 \\
100.0\end{array}$ & $\begin{array}{c}12.8 \\
100.0\end{array}$ \\
\hline Anxiety: & $\begin{array}{l}\text { Yes } \\
\text { No } \\
\text { Total }\end{array}$ & $\begin{array}{l}15 \\
32 \\
47\end{array}$ & $\begin{array}{c}31.9 \\
68.1 \\
100.0\end{array}$ & $\begin{array}{c}31.9 \\
68.1 \\
100.0\end{array}$ & $\begin{array}{c}31.9 \\
100.0\end{array}$ \\
\hline Failure: & $\begin{array}{l}\text { Yes } \\
\text { No } \\
\text { Total }\end{array}$ & $\begin{array}{c}6 \\
41 \\
47\end{array}$ & $\begin{array}{c}12.8 \\
87.2 \\
100.0\end{array}$ & $\begin{array}{c}12.8 \\
87.2 \\
100.0\end{array}$ & $\begin{array}{c}12.8 \\
100.0\end{array}$ \\
\hline Faillure now: & $\begin{array}{c}\text { Yes } \\
\text { No } \\
\text { Total }\end{array}$ & $\begin{array}{c}6 \\
41 \\
47\end{array}$ & $\begin{array}{c}12.8 \\
87.2 \\
100.0\end{array}$ & $\begin{array}{c}12.8 \\
87.2 \\
100.0\end{array}$ & $\begin{array}{c}12.8 \\
100.0\end{array}$ \\
\hline Disappointment: & $\begin{array}{l}\text { Yes } \\
\text { No } \\
\text { Total }\end{array}$ & $\begin{array}{c}7 \\
40 \\
47\end{array}$ & $\begin{array}{c}14.9 \\
85.1 \\
100.0\end{array}$ & $\begin{array}{c}14.9 \\
85.1 \\
100.0\end{array}$ & $\begin{array}{c}14.9 \\
100.0\end{array}$ \\
\hline
\end{tabular}

Frequency of students attending to class, many times $36.2 \%$ (17), quite a lot $36.2 \%$ (17), sometimes $12.8 \%$ (6), and a few $14.9 \%$ (7).

Teacher's degree of influence perceived by the students, many times $36.2 \%$ (17), a lot $46.8 \%$ (22), some classes $8.5 \%$ (4) and a few $8.5 \%$ (4). The $87.2 \%$ (41) of the students perceive a positive influence from the teacher and $12.6 \%$ (6) is indifferent to it, while none of the students reflect a negative influence.

A 78\% (37) of the students think about finishing their initiated studies, compared to a $2.1 \%$ (1) that does not even think about it and a $19.1 \%$ (9) have thought of doing it at some point. But when we asked the question in reverse about dropping out, we obtained that $12.8 \%$ (6) have thought about it and a resounding $87.2 \%$ (41) that haven't done it.

The feelings of anxiety, failure and disappointment obtained are: presence of anxiety $31.9 \%$ (15) and absence $68.1 \%$ (32); current failure or have suffered are both in equal percentage, with $12.8 \%$ (6) affirmative and $87.2 \%$ (41) negative; presence of disappointment regarding expectations put on the career was $14.9 \%$ (7) positive, against a great majority $85.1 \%$ (40) absent.

In this section will verify or reject the hypotheses that we had previously proposed, we will observe the results obtained in the research for each one of the hypotheses 
(Table 2).

After applying chi-squared, it is obtained:

Hypothesis 1 . Chi-squared value is 11.963 , with a sig.

0.63 , wherewith $p>0.05$ and the Ho was accepted.

Hypothesis 2. Chi-squared value is 0.87 with a sig. 0.768 , Ho is accepted again, so $p>0.05$.

Hypothesis 3. Chi-squared value is 0.485 with a sig. 0.784 , Ho is accepted by $p>0.05$.

Hypothesis 4 . Chi squared value is 6.688 with a sig. 0.01 , Ho is rejected by $p<0.05$. and we accept the Ha, confirming a dependence between variables.

Hypothesis 5. Chi-squared value is 8.563 with a sig. 0.03 , Ho is rejected by $p<0.05$, accepting the Ha and confirming a dependence between variables.

Hypothesis 6. Chi-squared value is 0.640 with a sig. 0.424 , Ho is accepted by $p>0.05$.

In the hypotheses, \#1, \#2, \#3 and \#6, the Ho was accepted, since there was not a significant contrast and thus Ha (object of study) were rejected. However it was verified again the possility of dependence between studied variables through likeliness and linear association, showing again siginifications $p>0.05$ confirming the absence of dependence. Regarding hypotheses 4 and 5 , if we reject Ho for having a dependence between the variables and Ha it has been accepted.

Table 2. Hypothesis.

\begin{tabular}{|c|c|c|c|}
\hline & \multicolumn{3}{|c|}{ HYPOTHESIS $1\left(\mathrm{H}_{0}\right)$} \\
\hline & Value & df & Asymp.Sig (2-sided) \\
\hline Pearson Chi-square & 11.693 & 6 & 0.063 \\
\hline Likelihood Ratio & 13.791 & 6 & 0.032 \\
\hline \multirow[t]{2}{*}{ Linear-by-linear Association } & 2.486 & 1 & 0.115 \\
\hline & \multicolumn{3}{|c|}{ HYPOTHESIS $2\left(\mathbf{H}_{0}\right)$} \\
\hline Pearson Chi-square & 0.087 & 1 & 0.768 \\
\hline Likelihood Ratio & 0.092 & 1 & 0.762 \\
\hline \multirow[t]{2}{*}{ Linear-by-linear Association } & 0.085 & 1 & 0.770 \\
\hline & \multicolumn{3}{|c|}{ HYPOTHESIS 3 ( $\left.\mathbf{H}_{0}\right)$} \\
\hline Pearson Chi-square & 0.485 & 2 & 0.784 \\
\hline Likelihood Ratio & 0.511 & 2 & 0.775 \\
\hline \multirow[t]{2}{*}{ Linear-by-linear Association } & 0.058 & 1 & 0.809 \\
\hline & \multicolumn{3}{|c|}{ HYPOTHESIS $4\left(\mathrm{H}_{0}\right)$ : } \\
\hline Pearson Chi-square & 6.688 & 1 & $0.010^{*}$ \\
\hline Likelihood Ratio & 5.028 & 1 & 0.025 \\
\hline \multirow[t]{2}{*}{ Linear-by-linear Association } & 6.545 & 1 & 0.011 \\
\hline & \multicolumn{3}{|c|}{ HYPOTHESIS 5 (Ho) } \\
\hline Pearson Chi-square & 8.563 & 1 & $0.003^{*}$ \\
\hline Likelihood Ratio & 6.117 & 1 & 0.013 \\
\hline \multirow[t]{2}{*}{ Linear-by-linear Association } & 8.380 & 1 & 0.004 \\
\hline & \multicolumn{3}{|c|}{ HYPOTHESIS $6\left(\mathrm{H}_{0}\right)$} \\
\hline Pearson Chi-square & 0.640 & 1 & 0.424 \\
\hline Likelihood Ratio & 1.146 & 1 & 0.284 \\
\hline Linear-by-linear Association & 0.626 & 1 & 0.429 \\
\hline
\end{tabular}

"Significant at $p<0.05$.

\section{CONCLUSIONS}

In the research conducted, through a systematic process of collecting information throughout surveys, we have detected a number of deficiencies and problems that are hindering and obstructing academic training of Nursing students at the University of Las Palmas de Gran Canaria.

In this study, some of the weaknesses are evidenced in the study habits and techniques that are done by university students, that hinder their academic development.

We have observed and analyzed through the data, that most students who wanted to abandon their career have been mainly by psychological problems, among others.

On the other hand, we have found that the teacher has a great influence on university students as evidenced by the fifth hypothesis "positive perception of teacher's influence by the student affects in the decreasing possibilities of failure feeling”. Also, university students believe that the relationship between teachers and students, being favourable, can influence in overcoming these subjects, otherwise, it hinders and has a negative impact on overcoming themselves.

As we can see in the fourth hypothesis that feeling of failure on university studies can be influenced by the failure of initial expectations about the degree chosen.

Similarly, we have also included that the percentages of negative aspects are higher than the rest, but does not constitute an absolute majority, thus, there are many students who bear the obstacles and end their studies successfully.

\section{DISCUSSION}

The weaknesses are evidenced in the study habits and techniques that are done by university students, which hinder their academic development. These techniques and habits are incorrect, inappropiate and have a low effectiveness for development, training and reaching objectives and guidelines established within university academic enviroment.

That most students who wanted to abandon their career, have mainly psychological problems, among others. Within the psychological factors we must relate primarily anxiety and stress. These factors are not linked to overcome certain subjects, the failure of goals and expectations set by the students, lack of time for preparing the work, mismanagement of study hours required, among others.

With the results presented in this research, we are trying to mark some objectives needed to cover the range of needs and students or university demands, with the purpose and aim of improving some negative aspects that hinder and represent a handicap for students' overcoming and academic training. 
The results of this research have shown us, that the main factor for failure or dropout affecting university students is a lack of time organization available for university students that are preparing and studying their exams, which will generate anxiety. So, teaching students to organize their time and work in the correct way to avoid anxiety and stress caused when leaving everything until the end is of vital importance.

The universities should be adapted to what they offer to new students, in addition to provide better information on the content of their careers and learning methodology, so students can have a greater freedom of choice and more realistic vision to what they are facing with their choice, as we can see in the fourth hypothesis "feeling of failure on university studies can be influenced by the failure of initial expectations about the degree chosen".

These deficiencies in students will have as a result not ending their training which includes not being able to access more skilled jobs and to be excluded from labor market, besides not progressing on the personal aspect for not reaching their goals.

With the results of such research, we pretend to use and direct them primarily at creating orientation cabinets for ULPGC students, where their demands and needs are met by qualified staff and where all the students have the right to access to it.

\section{ACKNOWLEDGEMENTS}

Thanks to Facultad de Ciencias de la Salud de la Universidad de Las Palmas de Gran Canaria and $2^{\text {nd }}$ course Nursing Students.

\section{CONFLICT OF INTERESTS}

The authors declare not having any conflict of interests.

\section{REFERENCES}

[1] Cabrera, L., Bethencourt, J., Alvarez, P. and González, M. (2006) El problema del abandono de los estudios universitarios. Relieve, 12.
http://www.uv.es/relieve/v12n2/RELIEVEv12n2_1.htm

[2] García Torres, B. (1983) Afectividad y rendimiento escolar. Cuadernos de Pedagogía, 103-104, 18-21.

[3] Núñez, J.C., González-Pienda, J.A., González-Pumariega, S., González Cabanach, R., Barca, A., Valle, A., Porto, A. and Santórum, R. (1995) Motivación, cognición y rendimiento académico. Revista Galego-Portuguesa de Psicoloxía e Educación, 12, 183-209.

[4] Carabaña, J. (1983) Le llamaban fracaso escolar. Cuadernos de Pedagogía, 103, 26-30.

[5] Riviere, A. (1983) Por qué fracasan tan poco los niños. Cuadernos de Pedagogía, 103-104, 7-12.

[6] Molina, S. and García, E. (1983) Fracaso del profesor o fracaso del sistema? Cuadernos de Pedagogía, 102-103, 22-26.

[7] Ventura De Pino, L. and Tavares, J. (1999) Expectativas de los alumnos, su nivel de aspiraciones e integración en la carrera y en la institución universitaria. http://www.aufop.com/aufop/uploaded_files/articulos/122 4340137.pdf

[8] Corominas, E. (2001) La transición a los estudios universitarios: Abandono o cambio en el primer año de universidad. Revista de Investigación Educativa, 19, 127-151.

[9] Cabrera, L., Bethencourt, J., Alvarez, P. and González, M. (2006) Un estudio transversal retrospectivo sobre prolongación y abandono de estudios universitarios. Relieve, 12, 105-27. http://www.uv.es/RELIEVE/v12n1/RELIEVEv12n1_1.p df

[10] Martín, E., García, L. and Hernández, P. (1999) Determinantes de éxito y fracaso en la trayectoria del estudiante universitario. La Laguna. Servicios de publicaciones Universidad de La Laguna. http://www.ijpsy.com/volumen8/num3/213/estrategias-de -aprendizaje-y-rendimiento-ES.pdf

[11] Tinto, V. (1986) Una reconsideración de las teorías de deserción estudiantil. Handbook of theory and research, 359-384.

[12] Holland, J.L. (1966). The Psychology of the vocational choice. Blaisdell, Walthau Mass. 